\title{
Prevenção de agravos à saúde do trabalhador: replanejando o trabalho através das negociações cotidianas
}

\author{
Preventing damage to workers' health: \\ redesigning jobs through day-to-day negotiation
}

Leny Sato 1

\footnotetext{
1 Departamento de Psicologia Social e do Trabalho, Instituto de Psicologia, Universidade de São Paulo. Av. Prof. Mello Moraes 1721 São Paulo, SP 05508-900, Brasil. lenysato@usp.br
}

\begin{abstract}
This paper reflects on prevention of harm to workers' health by redesigning jobs. Assuming redesign as the process of negotiating organizational choices, the author discusses the characteristics of routine negotiation at the workplace, illustrated by daily negotiations in work process organization at a Brazilian food-processing factory. Finally, the author discusses both the range and limits of such negotiations in the prevention of harm to workers' health.

Key words Negotiating; Accident Prevention; Social Psychology; Occupational Psychology; Occupational Health

Resumo Este artigo tem por objetivo apresentar algumas reflexões sobre a prevenção de agravos à saúde do trabalhador através do replanejamento do trabalho. Compreendendo o replanejamento como processo de negociação de escolhas organizacionais, apresenta as características das negociações cotidianas processadas no chão de fábrica e relata, a título de exemplo, um caso de negociação cotidiana que toma por objeto a organização do processo de trabalho da produção fabril de uma indústria de alimentos. Por fim, discute os alcances e os limites de tais negociações à luz da prevenção de agravos à saúde do trabalhador.

Palavras-chave Negociação; Prevenção de Acidentes; Psicologia Social; Psicologia do Trabalho; Saúde Ocupacional
\end{abstract}




\section{Introdução}

O replanejamento do trabalho é um tema que se insere num conjunto de preocupações relacionadas à saúde do trabalhador. Insere-se, especialmente, naquele conjunto de estratégias que visam prevenir determinados problemas de saúde, como por exemplo, os de saúde mental e psicossomáticos, as lesões por esforços repetitivos, os acidentes de trabalho, como mostram diversas evidências obtidas por pesquisas empreendidas com o apoio de referenciais teórico-metodológicos os mais diversos, e focando as diferentes categorias de trabalhadores (Borges, 1997; Dejours et al., 1994; Kalimo et al., 1987; Karasek et al., 1981; Kristensen, 1995; Seligmann-Silva, 1986, 1994; Seligmann-Silva et al., 1985, 1986; Silva Filho \& Jardim, 1997; Vezina, 1998).

A depender da forma como o processo de trabalho é organizado, o cotidiano no local de trabalho é configurado por contextos nos quais os modos de se trabalhar, de se relacionar, de lidar com o tempo, com o espaço e com os equipamentos são sabidamente danosos à saúde. A prevenção dos problemas de saúde que encontraria maior grau de resolução seria o replanejamento da organização do processo de trabalho, conforme argumentado por Gardell (1982a) e Spink (1991b).

Alguns exemplos mostram-nos que os trabalhadores criam formas para resistir à racionalidade imposta à organização do trabalho tal qual planejada pelo corpo gerencial, denunciando que os trabalhadores buscam constantemente melhorar a sintonia entre eles e os contextos de trabalho. Eles o fazem individual e coletivamente. Denunciam, com essas práticas, que a divisão entre planejadores e executores é, de fato, uma ideologia. Podemos observar diversas manifestações que mostram a existência de outras racionalidades, outros modos de conceber e fazer o trabalho nos limites dados pela tecnologia empregada e pela divisão de poderes no local de trabalho. Estudo clássico de Frederico (1979), descreve as formas através das quais operários de uma indústria automobilística na região do ABCD paulista resistiam ativamente às pressões da organização do processo de trabalho, demonstrando a concepção de distintos modos de se combinar a dimensão técnica e social do trabalho de modo a diminuir o ritmo, tais como a "operação-zêlo", a "operação-acidente”, a "operação-soluço", dentre outras. Menos visíveis do que aquelas “operações", os trabalhadores constroem "ações adaptativas" as quais têm por finalidade adequar os contextos de trabalho, no limite do possível, às características pessoais e aos limites subjetivos (Sato, 1993).

Evidências sobre a adoção de outras racionalidades para organizar o trabalho já foram demonstradas também pela psicologia industrial, quando estudos da Escola de Relações Humanas observaram, nos anos 20 do século XX (Brown, 1972), que as pessoas concebem outras formas de se trabalhar, atribuindo outros significados às prescrições e criando laços entre si. Tais vínculos são sustentados e sustentam a criação de regras próprias, e norteiam a realização do trabalho segundo modos distintos daquele concebido pelo grupo gerencial. Por serem vínculos criados à revelia da iniciativa gerencial, foram denominados de "grupos informais”. Também Daniellou et al. (1989), através das noções de "trabalho prescrito" e "trabalho real", reconhecem a existência de distintas realidades: distintas organizações. Não raro, o trabalho real conduz não apenas a um maior conforto aos trabalhadores, mas à economia $\mathrm{e}$ ao aperfeiçoamento do processo e, por isso, contemplam os interesses gerenciais e do capital.

Os exemplos acima reafirmam que, apesar de o corpo gerencial conceber a atividade de planejamento e concepção como procedimento de natureza estritamente técnica e conduzida unilateralmente por ele, no "chão de fábrica”, as pessoas, através do conhecimento construído na prática, o replanejam para então executá-lo, tanto com a finalidade precípua de amenizar os esforços do trabalho, como para manifestar a resistência política ao poder e controle gerenciais ou ainda, para tornar factível aquilo que foi planejado por outrem. Isso significa que a condução de assuntos cotidianos é norteada pela interpretação de regras, como mostra Clegg (1992) a respeito da "regra do mau tempo", empregada por trabalhadores da construção civil. Todas essas evidências reafirmam que a vida cotidiana - o chão de fábrica - é criada e recriada, é o lugar onde as pessoas dão sentido aos fazeres, orientados por métodos práticos, aquilo que é denominado "raciocínio sociológico prático” (Garfinkel, 1984). O conjunto de preceitos e técnicas denominado modelo japonês, reconheceu e tem utilizado as outras racionalidades que explicam a diferença entre o prescrito e o real, e construiu técnicas com o intuito de aproveitar o conhecimento dos trabalhadores visando aprimorar os processos de trabalho. Assim, as técnicas de kaisen e muda, os CCQs, são expressões orientais desse reconhecimento, substituindo as obsoletas caixinhas de sugestões. É também nesse sentido que vemos a adoção dos programas de empowerment. 
Considerando-se então que existem formas de organização do trabalho reconhecidamente danosas à saúde, e que há uma busca contínua em adotar outros modos de combinar os sistemas técnico e social, guiados por outras racionalidades, o replanejamento seria o modo através do qual o cotidiano no local de trabalho pode ser publicamente modificado. Para pensar-se em como fazê-lo, é necessário que seja trazida à luz a concepção sobre o que é o local de trabalho: quais são seus elementos, como ele é construído, qual o papel das pessoas; ou seja, o que é uma organização. A depender da concepção adotada, identificaremos distintas maneiras de pensar, como planejar/replanejar o trabalho.

Como nos fala Spink (1991a:23-24), “durante muito tempo, pelo menos até a década de 30 , organização, enquanto palavra descritora, foi associada à necessidade de dar ou colocar ordem (ordenar) nas diversas ações que formavam os empreendimentos industrial, comercial ou o serviço público. A arte de administrar desenvolveu-se em torno das atividades de planejar, organizar, liderar $e$ controlar. Conseqüentemente, a organização de atividades faz parte do empreendimento ou serviço, embora não seja sua característica principal". Outra concepção de organização é proveniente, como continua nos falando Spink (1991a:24), da antropologia, para a qual, a palavra organização é utilizada de maneira genérica, "para referir-se a processos sociais em agregações humanas, suas religiões, seus ritos, sua estrutura familiar e seu modo de vida. Ninguém duvidava que esses processos sociais tinham seu lado simbólico". Vale dizer que esses processos sociais são informados também por interesses de diversas ordens: do capital e do trabalho, das pessoas e de seu grupo social (como por exemplo, os religiosos e éticos), das tarefas, dos cargos e dos setores de trabalho, conforme uma das metáforas descritas por Morgan (1986), para compreender as organizações.

Na década de 50, consolida-se a criação do campo profissional gerencial, o que exige um espaço delimitado para o exercício ideologicamente legitimado da atividade gerencial. Isso traz a necessidade de se criar um objeto para se estudar. "A palavra organização tem seu significado alterado. Agora passa a ser um objeto a ser estudado, uma espécie de baú, dentro do qual comportamentos podem ser observados, crescendo a discussão sobre suas características e seu gerenciamento" (Spink, 1991a:24).

Diferentes formas de conceber o que é organização privilegiam diferentes atores, legitimam uns e não outros como os que têm a prer- rogativa para pensá-la, estudá-la, planejá-la e replanejá-la; enfim, construi-la e conduzir seus processos. Assim, vinculada à concepção da organização como baú, tem-se aquela que pensa as pessoas apenas como uma parte de uma engrenagem ou, no máximo, quando se vê a dimensão humana da organização, busca-se prever e normatizar o comportamento das pessoas nas situações de trabalho, o que se sustenta em modelos simplistas de homem. Dessa forma, o taylorismo e o fordismo - concepções essas ainda fortemente presentes nos locais de trabalho - institui e legitima como prerrogativa de alguns, o papel de e o poder para planejar como coisas deverão ser produzidas e serviços prestados, combinando-se tecnologia, valores sociais, preferências pessoais, etc. Diga-se de passagem que, apesar de toda a série de mudanças organizacionais adotadas no âmbito do que chamamos de reestruturação produtiva, os princípios da mecânica para planejar o que os trabalhadores farão ainda estão fortemente presentes.

A cada uma dessas concepções de organização aliam-se aquelas relativas ao planejamento/replanejamento do trabalho. De Lanzara (1985), extraímos duas perspectivas. Na primeira, temos que planejar o que as pessoas farão, quais, como e quando serão feitas as atividades é um procedimento de natureza estritamente técnico-funcional. Para a segunda, planejar é uma atividade dialógico-discursiva, ou seja, é um processo de interação onde as pessoas argumentam e contra-argumentam, defendendo e atacando as diferentes possibilidades de realizar-se o trabalho, procedendo-se, assim, a "escolhas organizacionais" (Kelly, 1978), conceito esse trazido pela escola sociotécnica. Ao considerar-se que o planejamento/replanejamento é fruto de escolhas, afasta-se a hipótese de que há um melhor modo de fazer, afirmando-nos que não há apenas um racional a ser adotado. Tais escolhas dão-se em contextos políticos, pois interesses diversos estão em jogo e buscam ser contemplados - interesses da produção, dos trabalhadores, da gerência, dos proprietários, do capital e do trabalho. Dessa forma, podemos definir os processos de planejamento/replanejamento como processos negociados de escolhas: processos de negociação. A negociação é definida como "processos discursivos através dos quais se barganha o controle sobre a organização do processo de trabalho" (Sato, 1997:27).

Como diz Lanzara (1985:60-61): “projetar e construir uma casa, por exemplo, pode ser um processo puramente técnico ou pode ser um processo em grande parte ritual: a estrutura de 
planejamento nos dois casos é completamente diferente, os elementos componentes são diferentes, os critérios de seleção são diferentes, as regras para a composição dos elementos e os significados atribuídos às regras e às ações são diferentes (...) O resultado do planejamento $-a$ casa - pode ser visto como o produto de um processo sustentado por uma estrutura decisional, ou como fruto de uma análise funcional, ou como um universo de elementos simbólicos evocados e produzidos, compativeis mediante um cerimonial conduzido coletivamente".

Apesar de existirem concepções que argumentam em favor de que as organizações não são baús e sim processos de interação social em contextos políticos e, portanto, que o planejamento/replanejamento da organização do trabalho não é uma atividade meramente técnica mas constitui-se em uma atividade de interação comunicativa (negociação), a herança tecnicista concebeu e conduziu a que o planejamento do trabalho fosse realizado baseado na primeira concepção: a de uma atividade estritamente técnica, sustentada pela ideologia gerencial, que a engenharia, a administração, a psicologia, dentre várias outras disciplinas têm contribuído para sustentá-la. Tal ideologia defende que a atividade de planejar é uma prerrogativa de determinados grupos dentro dos locais de trabalho, concebendo-a como atividade neutra e entendendo que essa neutralidade é possível pois está baseada na ciência. Veja-se, por exemplo, a ideologia profissional que sustenta a trajetória da psicologia do trabalho e organizacional, criticada por Prilleltensky (1994), ao concluir que ela tradicionalmente caminha no mundo do trabalho a partir de duas premissas: a de que o mundo do trabalho é desprovido de conflitos e de que a psicologia é ciência, e que a ciência é bom para todos, indistintamente.

Bem, mas o ouvinte atento imediatamente lançaria a pergunta: mas como é possível conceber o planejamento/replanejamento como processo negociado, como uma prática passível de efetivação nas empresas privadas no Brasil, uma vez que há fortes evidências de que a assimetria de poder nesses locais de trabalho é fator impeditivo para a democratização da fala? Ou, em outras palavras: como é possível conceber a negociação quando o local de trabalho é um espaço privado e, como tal, impede que argumentos sejam validados por critérios de justiça, veracidade e sinceridade (Habermas, 1987a, 1987b) e não pela coação?

Essas questões nos conduzem à tematização sobre o que é entendido por negociação. Em geral, quando pensamos em negociação, a primeira imagem que nos toma é a de representantes dos trabalhadores e dos patrões sentados à mesa, negociando. Em geral, é o modelo da negociação coletiva que temos em mente. Nele temos os representantes claramente definidos (eleitos ou indicados), buscando chegar a acordos válidos para uma empresa, para uma categoria profissional ou para diversas categorias filiadas a uma central sindical. Nesse modelo, teríamos condições de negociação apenas quando os trabalhadores conseguissem ter uma organização política forte e os órgãos de representação tivessem, de fato, representatividade. No Brasil, sabemos, os processos negociados de celebração de acordos é bastante restrito, pois temos uma história de autoritarismo político e uma legislação trabalhista de forte cunho paternalista, onde tudo se resolve na Justiça do Trabalho (Rodrigues, 1974; Simão, 1981). Sabemos também da dificuldade em construir as Organizações no Local de Trabalho (OLTs) (Rodrigues, 1991, 1994), bem como em fazermos das Comissões Internas de Prevenção de Acidentes (CIPAs) órgãos que, de fato, tenham uma atuação que leve em conta os interesses dos trabalhadores. O próprio conceito de trabalho está fortemente impregnado pela nossa herança escravagista. Como diz Ianni (1994:5758), "os séculos de trabalho escravizado produziram todo um universo de valores, padrões, idéias, doutrinas, modos de ser, pensar e agir". Além disso, o nosso passado colonialista e sua versão recente, o imperialismo, estão presentes no nosso cotidiano.

Mas é também Otávio Ianni, quem reconhece que o Brasil é um mapa arqueológico, onde o passado, o presente e o futuro convivem sem problemas. "O presente capitalista, industrializado, urbanizado, convive com vários momentos pretéritos. Formas de vida e trabalho díspares aglutinam-se em um todo insólito. A circulação simples, a circulação mercantil e a capitalista articulam-se em um todo no qual comanda a reprodução ampliada do capital, em escala internacional" (Ianni, 1994:60-61). Vejamos um exemplo desse mapa arqueológico, contado por Caldeira (1995): o Barão de Mauá, ainda no Brasil Império, onde o sistema de trabalho escravo era a relação de trabalho em voga, tivera em suas empresas trabalhadores livres e adotara o sistema de administração participativa e a distribuição de lucros, que hoje, no Brasil, vemos como objeto de debate entre os trabalhadores e empresários.

Ainda que não tenhamos uma história do trabalho no Brasil, em que a interlocução direta entre trabalhadores e patrões seja o modo de se relacionar, barganhar interesses e conquis- 
tar direitos, o reconhecimento desse mapa arqueológico conduz-nos a olhar as condições de possibilidade para desenvolver-se processos de negociação a partir de outros olhos. São também com outros olhos que, advogamos, devemos ver o local de trabalho: olhos que concebam a existência de pessoas e, como tal, buscam dar sentido ao seu cotidiano, construindo-o de modo conflituoso e cooperativo; pessoas que articulam a vida fora do local de trabalho com a vida no trabalho, lidam com as exigências postas pelas condições e pela organização do trabalho, enfim, conduzem processos sociais, constroem modos de vida. Assim, apesar de termos muitas vezes toda uma categoria profissional submetida a exigências comuns em termos de organização do processo de trabalho, quando nos aproximamos dos locais onde trabalham vemos que cada local é um mundo singular, com seus problemas particulares, com mecanismos que fazem com que uma mesma tecnologia influa diferentemente pois são pessoas diferentes, são relações interpessoais desigualmente construídas, são diferentes regras que vigoram.

\section{Astúcia e ambigüidade: características das negociações cotidianas}

É justamente na particularidade do universo de cada local de trabalho que são conduzidas outras formas de negociação qualificadas de cotidianas (Sato, 1997). São micronegociações, praticamente invisíveis ao visitante esporádico ou menos atento. São práticas que visam o alcance de acordos - apesar da reconhecida assimetria de poder e controle - e que constroem outros modos de se realizar o trabalho, configurando-se como processos de replanejamento negociados. Elas ocorrem independente da ação política coletiva que pressuponha uma estratégia articulada, e da existência de sindicatos combativos ou de OLTs e CIPAs também combativas. São conduzidas por pessoas comuns.

Se observarmos atenta e pacientemente o dia-a-dia dos locais de trabalho, veremos que há uma série de imprevistos, de novidades que irrompem em meio ao seu funcionamento repetitivo, mesmo naqueles processos onde as atividades também são repetitivas, realizadas por trabalhadores fixos em seus postos de trabalho, com ciclos extremamente curtos, como, por exemplo, as atividades de embalagem e empacotamento. Esse funcionamento expressa que, cotidianamente, uma série de "situações problemáticas" têm vez no local de trabalho e devem ser equacionadas e resolvidas. Essa de- nominação - situações problemáticas - designa situações previstas ou não, que devem ser resolvidas, pois implicam em problemas. São problemáticas porque afetam interesses de alguma ordem e de alguém. Por exemplo: doenças do trabalho, esforço demasiado, afastamento de trabalhadores, perda de material, retrabalho, depreciação da qualidade do produto. Essas situações são acontecimentos que apenas ganham significado quando postos em relação a interesses. As doenças do trabalho são fatos que ganham o status de situação problemática quando postas em relação aos interesses dos trabalhadores. Do mesmo modo, a perda de material é um tipo de acontecimento que se torna uma situação problemática quando posta em relação aos interesses dos proprietários e acionistas.

A resolução negociada dessas situações dáse mediante a construção de significados que possibilitam, digamos assim, "iniciar a conversa” pois que a negociação só se torna possível quando as partes em conflito conseguem minimamente vislumbrar a existência das diferenças; olhar, ainda que parcialmente, a perspectiva, os problemas e os interesses alheios. É essa possibilidade de "início de conversa" que denominamos de "base simbólica” (Sato, 1997), ou seja, o requisito simbólico para que se inicie o processo de negociação. Certamente, além desse requisito para que a negociação se processe, há aquele de ordem política: o poder de barganha.

Foi através de situações problemáticas que pudemos acessar e caracterizar o requisito simbólico para a negociação, assim definido: a base simbólica é o conjunto de significados polissêmicos, estruturados pelo conflito de interesses e dinamizado pelos processos de "comfusão" de interesses e de "deslocamento" de posições. Explicando: o conflito de interesses é requisito necessário para que sejam observados os processos de negociação, daí porque ele constituir a estrutura do requisito simbólico. Isso porque em não havendo diferenças de interesses que, em relação, configuram uma situação de conflito, não há motivo para negociar. Por sua vez, os dois processos que dinamizam a base simbólica demonstram como no dia-a-dia a relação de interesses é complexa. Em primeiro lugar porque há uma infinidade de interesses presentes. Em segundo porque, ainda que possamos ver e distinguir a pluralidade de interesses, o mais comum é que eles se apresentem misturados, muitas vezes escamoteados, mimetizados, daí porque denominamos um dos processos de "com-fusão" de interesses, pois um mesmo acontecimento pode, 
simultaneamente, ser uma situação problemática para a gerência, para os acionistas, para os consumidores e para os trabalhadores. Esse processo separa interesses que deveriam estar juntos (como os dos trabalhadores) e funde interesses que deveriam estar separados (como os dos trabalhadores e os da gerência). Vejamos um exemplo: a fabricação de produtos fora das especificações pode atingir os interesses da produção, mas pode significar, simultaneamente, maior volume de trabalho para os operadores pois deverão acertar o funcionamento da máquina. De outro lado, a alta prevalência de doenças do trabalho representa, para os trabalhadores, o prejuízo para a saúde e para a capacidade de trabalho, mas pode, simultaneamente, representar para a gerência e para os proprietários, o comprometimento da produtividade e da qualidade.

O segundo processo - "deslocamento" de posições - demonstra que, apesar de existirem posições definidas no local de trabalho, posições essas que expressam e defendem os interesses, constantemente as pessoas mudam de posição. As posições são dadas e assumidas pelos papéis de trabalho, são dadas pela divisão de diferentes setores e, também, por posicionamentos pessoais e de classe social. E essa mudança é possibilitada também pela própria organização do processo de trabalho, que cria postos e tarefas nos quais interesses estão embutidos. Esse "deslocamento" possibilita que as pessoas se aproximem do lugar ocupado pelas outras e, assim, possam vislumbrar interesses diferentes e opostos. Esse processo cria condições para que observemos situações inusitadas pois, se num primeiro momento uma determinada pessoa, assumindo um determinado papel de trabalho defende um interesse, em outro, por mudar de posição, passa a atacar esse mesmo interesse.

A ambigüidade da base simbólica criada por esses dois processos explica avaliações de que há pessoas que têm duas caras. Como nos fala Chaui (1993:121), a ambigüidade, a qual define que algo é "isto e aquilo ao mesmo tempo", possibilita tematizar o atraso e a emancipação, a capacidade de se conformar ao resistir e de resistir ao se conformar. Por isso, o caráter ambíguo da base simbólica remete tanto às possibilidades de negociação como ao acirramento dos conflitos.

Se de um lado essa ambigüidade é um elemento que dificulta a clara conformação de interesses e, portanto, do claro posicionamento das pessoas, por outro, é ela que possibilita processar negociações no local de trabalho em contextos de poder e controle assimétricos.
Como dissemos anteriormente, as negociações cotidianas são quase invisíveis, observadas e reconhecidas quando o olhar atento consegue ver que os acontecimentos no local de trabalho têm significados e que as pessoas buscam lidar com as situações que se apresentam como problemáticas. Esses processos de negociação foram qualificados como astuciosos por adotarem estratégias e táticas de modo a que o fraco possa existir frente ao forte; por exemplo, reconhecendo a existência de um discurso gerencial, e aproveitando-se dele. Criam-se mecanismos de resistência no seio do conformismo (Chaui, 1993) ou, como nos fala Certeau (1994), criam-se táticas de modo que o colonizado escape ao poder do colonizador sem, no entanto, deixá-lo.

A astúcia reside na capacidade de aproveitar-se da ambigüidade das situações problemáticas, da "com-fusão" de interesses e do conhecimento possibilitado pelo "deslocamento" de posições. É através desse deslocamento que são extraídos argumentos utilizando-se da linguagem permitida pois, como disse um trabalhador, "aqui todo mundo tem que falar a mesma língua”. A astúcia leva alguns trabalhadores a esconderem suas reivindicações em "sugestões de melhoria”, um claro eufemismo, mas que só assim interesses opostos aos da gerência e do capital podem ter passagem, serem expressos e ouvidos. Só através do controle da expressão do mundo subjetivo (vivências e sentimentos), interesses pessoais ou do grupo de operários podem ser apresentados (Goffman, 1985). A apresentação pública, verbal e não-verbal, dá-se de modo a esconder a existência de conflitos de interesse.

Um exemplo desses mecanismos astuciosos é o uso do discurso da "qualidade". Uma primeira aproximação com os discursos sobre a "qualidade" veiculados na fábrica, dá-nos a impressão de que a ideologia gerencial é totalmente eficaz. A princípio, todos, indistintamente, referem-se à necessidade de se trabalhar com qualidade. Uma primeira conclusão a que somos levados é a de que os trabalhadores estão em comunhão com os interesses da gerência, dos proprietários e dos consumidores. Porém, ao nos afastarmos desse núcleo vemos a polissemia que a noção de "qualidade" conserva. Ela possibilita que diversos argumentos sejam ancorados nesse núcleo, levando a defender interesses os mais diversos e até mesmo opostos. Assim, para alguns, trabalhar com qualidade implica na economia de tempo, de pessoas e de matérias-primas, enquanto para outros significa diminuir o ritmo de funcionamento das máquinas. 


\section{A linha de cima e a linha de baixo: um caso de negociação cotidiana}

Um exemplo de como se processam essas negociações cotidianas, sustentadas pela astúcia das táticas e pela ambigüidade do significado dos acontecimentos, nos vem de uma fábrica de produtos alimentícios. Trata-se de um caso envolvendo duas linhas de produção: (1) a de preparação de embalagens (impressão a jato de tinta) e (2) a de envasamento de produto. A primeira linha alimenta a segunda. Espacialmente, as linhas não estão contíguas; a primeira está alocada no subsolo (a linha de baixo) e a segunda no térreo (a linha de cima). Os potes separados e já impressos, são transportados por elevador e distribuídos pelas diversas linhas de envasamento de produtos. O transporte é feito pelos operários que trabalham na linha de impressão. No subsolo são realizadas todas as tarefas de preparação de embalagens e no térreo estão as linhas que dão identidade à fábrica e ao produto.

O caso de negociação cotidiana tem início com a insatisfação dos operários da linha de preparação de embalagens, e levou ao questionamento da delimitação de papéis e de fronteiras entre as duas linhas de produção. A primeira linha, a linha de baixo, operada pelos meninos (operários não qualificados) imprime a data de validade nos potes a serem envasados pela segunda linha, a linha de cima, onde o produto ganha a sua identidade pois recebe a embalagem e os rótulos com os símbolos da empresa. É na linha de cima que estão os trabalhadores qualificados, os operadores de máquina, que controlam o ritmo das máquinas, a qualidade do produto e coordenam o trabalho de vários operários não qualificados, em geral mulheres que envasam, embalam e empacotam os produtos. Diga-se de passagem que as "linhas de cima" estão situadas no local onde as visitas são levadas à fábrica, pois é lá que os produtos ganham a sua identidade, o rótulo com o nome e o logotipo da empresa. É lá que se reconhecem os produtos da empresa vendidos ao consumidor e que a empresa se reconhece nos produtos fabricados.

Tudo tem início com o seguinte fato: para fins de segurança e controle, deve haver sincronia entre o horário de envasamento dos produtos e aquele impresso nos vasilhames (horário, data, número de lote e de unidade fabril). Quando isso não ocorre, os dados já impressos devem ser apagados a fim de reaproveitar as embalagens de plástico. Trata-se de um trabalho manual, onde os dados são apagados, vasilhame por vasilhame. E esse retrabalho era fei- to pelos meninos. Um desses meninos, Josildo, descontente com esse procedimento - pois isso significava maior volume de trabalho e de uma atividade considerada ruim - disse: "eu sou contratado para carimbar e não para apagar!" Essa frase denuncia que a resolução dada para resolver a situação problemática para a gerência e para os operadores (falta de sincronia entre horário de envasamento e aquele impresso no pote), conduziu a uma situação problemática para os meninos (apagar a impressão dos potes). Essa frase foi o primeiro argumento que levou Josildo e seus colegas de linha a buscarem mecanismos para equacionar e resolver essa situação de um modo diferente, a fim de levar a outras "escolhas organizacionais" (Kelly, 1978).

O primeiro passo adotado pelos meninos foi conhecer o processo de trabalho, visando identificar como aquela situação problemática poderia ser assim também configurada para os operários da linha de cima. Aqui operou-se o processo de "deslocamento" de posições, pois assim puderam colocar-se no lugar dos operadores de máquina e dos embaladores e embaladoras. Observaram então que, em não havendo coincidência entre o horário carimbado nos potes e o que efetivamente o produto fora fabricado, os operadores deveriam preencher um relatório acusando esse fato, o que poderia depor contra eles, uma vez que esse procedimento poderia ser interpretado como falta de competência ou de esforço por parte deles. Por outro lado, quando as máquinas da linha de cima paravam, as embaladoras - as mulheres ficavam sem atividade temporariamente, à espera da reativação da máquina. Na avaliação dos meninos as "mulheres ficam de braços cruzados". Observaram ainda que o risco de degradação da qualidade do produto aumentava quando era envasado em vasilhames excessivamente manuseados (carimbados e apagados), aumentando a probabilidade de ocorrência da perda de material ou de retrabalho, o que não seria bom nem para os operadores, nem para os supervisores, líderes e gerente de produção.

Com essas informações, angariadas através do processo de "deslocamento" de posições, os meninos trataram de construir argumentos e fazer com que essa situação - apagar o carimbo dos vasilhames - fosse problemática também para outras pessoas envolvidas na situação (supervisores, líderes, operadores e para as “mulheres"). Tratou-se, para isso, de construir mecanismos para que outros interesses fossem também atingidos, criando e aproveitando-se da "com-fusão" de interesses. Com essas informações, os meninos começaram a se recusar a 
apagar o carimbo dos vasilhames ou, quando apagar era inevitável, começaram a convocar as "mulheres" que ficavam de "braços cruzados" a também fazê-lo. Recorreram ao supervisor de produção para exigir respeito pela atividade deles, sugerindo sua intermediação para negociar regras de trabalho com os operadores de máquinas. Os meninos requeriam um procedimento aparentemente simples: o de que fossem avisados quando a máquina da linha de cima fosse parada. Apenas aparentemente é simples porque, na verdade, essa alteração de procedimento demandou a mudança de status da linha de cima em relação à linha de baixo e, também, mudança de status dos meninos em relação aos operadores de máquina. Os meninos, na verdade, reclamavam que a linha de baixo fosse considerada em sua singularidade - diferente da linha de cima, com pessoas diferentes que têm interesses próprios - procurando desfazer a imagem de que a linha de baixo é apenas um prolongamento da linha de cima e de que, portanto, os interesses são idênticos. Ao final desse processo, a mudança observada não exigiu a adoção ou criação de tecnologias sofisticadas, mas apenas a preocupação dos operadores em avisar os meninos sobre o andamento da linha de cima, através de um telefonema ou de um grito pelo elevador de transporte de embalagens. Delimitaram-se fronteiras entre linhas, evitando-se o desconforto de terem interesses diferentes em "com-fusão".

\section{Refletindo sobre a prevenção em saúde do trabalhador}

Esse processo de replanejamento negociado micronegociação - questionou uma escolha organizacional até então adotada que estava baseada em regras, valores, preceitos e preconceitos que alocavam, meninos, mulheres, operadores, linha de cima e linha de baixo, em regiões distintas, hierárquicas, no grande mapa simbólico da fábrica, mostrando-nos que o simbólico não se constitui em um mero acessório na organização material das pessoas e coisas no trabalho, mas é a própria realidade. Tal processo questionou também a ideologia gerencial, desafiando os lugares de competência tradicionalmente atribuídos aos gerentes, técnicos, supervisores, operários denominados de “qualificados" e de "não qualificados" (Attewell, 1990). Demonstrou o desenvolvimento de uma atividade de pesquisa aplicada realizada pelos meninos, onde as alternativas para a mudança levaram em consideração as exigências técnicas e as sociais.
Cabe lembrar que esse processo foi conduzido sem que houvesse a concorrência de técnicos, pesquisadores ou assessores especialistas em organização do processo de trabalho, em mudança organizacional ou em saúde do trabalhador.

Essa negociação cotidiana representou uma mudança qualitativa em termos de aumento de controle dos trabalhadores da linha de carimbo de vasilhames, ainda que, para o estrangeiro, nenhuma mudança visível, palpável e digna de nota pusesse ser vista. Apesar da invisibilidade para o estrangeiro, essa mudança obrigou a que se reconhecesse que linhas diferentes têm interesses e ritmos diferentes, que pessoas diferentes vêem as situações de modos diferentes e que têm interesses pessoais, sociais e de trabalho também diferentes. Com essa mudança que levou à diminuição do volume de trabalho, os meninos puderam distribuir e balancear o volume de atividades de modo mais adequado aos seus interesses e limites, extinguindo a tarefa de apagar carimbos e tendo maior possibilidade de programar o trabalho em função do funcionamento real da linha de cima. Com isso, aumentou-se a possibilidade de ter-se intervalos maiores para o almoço ou para o lanche, criando-se, ao mesmo tempo, condições para negociação intralinha (quando fazer pausas, quando imprimir, possibilitada pelo fato de a linha de baixo ser acionada pelos operários). Muitas outras negociações cotidianas ocorrem no local de trabalho e, assim como essa, são pouco evidentes pois poucas alterações trazem para a feição das linhas. Porém, se perguntarmos aos meninos se isso representou uma mudança significativa em suas condições de trabalho, veremos que sim. Também devemos referir que existem tentativas frustradas de replanejamento negociado, e que há muitas imposições de mudança por parte da gerência, expressão do mapa arqueológico (Ianni, 1994).

Esse caso de replanejamento negociado do trabalho, conduzido pelos operários das duas linhas nos faz pensar algumas coisas sobre planejamento/replanejamento, sobre negociação e organizações.

Muitas vezes pensamos que mudanças na organização do processo de trabalho - quer estejam elas voltadas para a prevenção de problemas de saúde ou melhoria da produtividade e qualidade - é um processo que mudará a organização como um todo. Esse caso nos mostra justamente o contrário. O replanejamento negociado do trabalho deu-se numa parte (Spink, 1991a), entre duas linhas, envolvendo algumas pessoas, o que corrobora a concepção de que planejamento/replanejamento do trabalho é 
também um processo de interação social e não apenas aplicação de técnicas (P. Spink, comunicação pessoal).

Devemos ter em mente que muitos dos processos de replanejamento do trabalho que visam melhorar as condições de saúde, podem, simultaneamente, melhorar a qualidade do processo (evitar retrabalho e perda de material) e a qualidade do produto, graças à polissemia das situações problemáticas, devido, principalmente, ao processo de "com-fusão" de interesses. Nesse sentido, consideramos importante reconhecer que, apesar de termos, no local de trabalho, interesses opostos e contraditórios, eles também se relacionam de maneira surpreendente e imprevisível, nos deixando confusos.

Apesar de o poder e o controle estarem, no local de trabalho, claramente em favor do corpo gerencial e do capital, astuciosamente, os trabalhadores criam mecanismos para que se processem negociações. Nesse sentido, muito embora não seja observada uma realidade na qual a ação comunicativa se dê, pois que não se encontra um contexto político de democracia radical (Habermas, 1987a, 1987b), argumentos que levem em conta o mundo das coisas, o das normas e o mundo subjetivo, encontram espaço de expressão através da ação dramatúrgica (Habermas, 1987a, 1987b). Assim, o “espaço público", igualmente defendido por Dejours (1998) como aquele em que, também no local de trabalho, as diversas opiniões podem ser confrontadas, é arrancado à força do “espaço privado" da fábrica. Claro deve estar que por esses motivos, há limites no alcance dessas negociações. São os acordos possíveis, mas reconhecemos também que elas têm alcances consideráveis, caso tomemos como referência o ponto de vista de quem está no local de trabalho e não o nosso, que estamos de fora, como espectadores críticos, no mais das vezes esperando grandes mudanças - no todo - prontamente visíveis. Consideramos que não podemos ter nem um olhar ingênuo - que considera resolvido o problema do planejamento/replanejamento da organização do processo de trabalho e da prevenção em saúde do trabalhador através dessas negociações cotidianas - e nem um olhar arrogante - que apenas vê como mudanças aquelas que assim consideremos.

Entendemos, seguindo Gardell (1982b), que o replanejamento do trabalho visando a promoção da saúde, deverá ser conduzido em múltiplos níveis - o das centrais sindicais, dos sindicatos, das OLTs e CIPAs e dos trabalhadores comuns - aproveitando-se da força que cada um deles tem. Como diz Myiamoto (1992:5354), um samurai heterodoxo que viveu no sé- culo XVII: "o fogo pode ser grande ou pequeno, mas possui sempre extraordinária força de transformação. O mesmo se sucede com as batalhas, cujos mandamentos são iguais tanto no combate de um contra um como nos confrontos de exércitos de dez mil homens de cada lado. Qualquer situação precisa ser considerada tanto sob a ótica do conjunto (o grande) quanto dos pormenores (o pequeno). Apreende-se o conjunto facilmente, enquanto os detalhes só podem ser percebidos por um olho muito atento".

São, as organizações, processos de interação social onde pessoas, também investidas de papéis de trabalho, procuram fazer valer seus interesses, seus valores e crenças; onde, para decifrá-la, devemos ter, sobretudo, a certeza de que no local de trabalho, apesar de o corpo gerencial e o capital buscarem "recursos humanos", as pessoas continuam sendo pessoas, apesar das exigências das condições de trabalho e de processos de trabalho organizados para aqueles "recursos".

No que se refere especificamente à saúde do trabalhador, reconhecer a existência das micronegociações pode ser relevante no sentido de que, para além de os trabalhadores serem portadores do conhecimento/subjetividade operária, conforme tematizado por Oddone et al. (1986), garantindo-lhes o papel de sujeitos na definição do que deve ser objeto da melhoria das condições de trabalho e saúde, eles são atores que conduzem mudanças, no limite do possível, visando a preservação da saúde. O conhecimento/subjetividade operária e as micronegociações são fenômenos da mesma ordem: os trabalhadores são construtores de conhecimento, articulam-se de modo conflituoso e cooperativo, e criam modos de vida singulares nos locais de trabalho. A construção do conhecimento prático e condução das micronegociações são empreendidos mediante pesquisas aplicadas, realizadas pelos trabalhadores. Em nosso entender, a riqueza desses fenômenos para a área da saúde do trabalhador reside no fato de que a prática dos profissionais que nela atuam, será a de interlocutores que venham a facilitar o processamento do planejamento/replanejamento do trabalho, concebida como atividade dialógico-discursiva (Lanzara, 1985), potencializando e ampliando as mudanças de organização do processo de trabalho, conduzidas sempre, a partir do grupo primário de trabalho. 


\section{Referências}

ATTEWELL, P., 1990. What is skill? Work and Occupations, 17:422-447.

BORGES, L. H., 1997. Trabalho e doença mental: Reconhecimento social do nexo trabalho e saúde mental. In: A Danação do Trabalho - Organização do Trabalho e Sofrimento Psíquico (J. F. Silva Filho \& S. Jardim, org.), pp. 193-202, Belo Horizonte: Te Corá Editora.

BROWN, J. A. C., 1979. Psicologia Social da Indústria. São Paulo: Atlas.

CALDEIRA, J., 1995. Mauá: O Empresário do Império. São Paulo: Companhia das Letras.

CERTEAU, M., 1994. A Invenção do Cotidiano. Artes de Fazer. Petrópolis: Vozes.

CHAUI, M., 1993. Conformismo e Resistência. Aspectos da Cultura Popular no Brasil. São Paulo: Brasiliense.

CLEGG, S., 1992. Poder, linguagem e ação nas organizações. In: O Indivíduo na Organização - Dimensões Esquecidas (J.-F. Chanlat, org.), pp. 37-66, São Paulo: Atlas.

DANIELlOU, F.; LAVILLE, A. \& TEIGER, C., 1989. Ficção e realidade do trabalho operário. Revista Brasileira de Saúde Ocupacional, 17:7-13.

DEJOURS, C., 1998. Souffrance en France - La Banalisation de l'Injustice Sociale. Paris: Seuil.

DEJOURS, C.; ABDOUCHELI, E. \& JAYET, C. (org.), 1994. Psicodinâmica do Trabalho - Contribuições da Escola Dejouriana à Análise da Relação Prazer, Sofrimento e Trabalho. São Paulo: Atlas.

FREDERICO, C., 1979. A Vanguarda Operária. Coleção Ensaio e Memória 24. São Paulo: Símbolo.

GARDELL, B., 1982a. Scandinavian research on stress in working life. International Journal of Health Services, 12:31-41.

GARDELL, B., 1982b. Worker participation and autonomy: A multilevel approach to democracy at the workplace. International Journal of Health Services, 12:527-558.

GARFINKEL, H., 1994. Studies in Ethomethodology. New Jersey: Prentice Hall.

GOFFMAN, E., 1985. A Representação do Eu na Vida Cotidiana. Petrópolis: Vozes.

HABERMAS, J., 1987a. Teoria de la Acción Comunicativa. Tomo I - Racionalidad de la Acción y Racionalización Social. Madrid: Taurus.

HABERMAS, J., 1987b. Teoria de la Acción Comunicativa. Tomo II - Crítica de la Razón Funcionalista. Madrid: Taurus.

IANNI, O., 1994. A Idéia de Brasil Moderno. São Paulo: Brasiliense.

KALIMO, R.; EL-BATAWI, M. \& COOPER, C. L. (ed.), 1987. Psychosocial Factors at Work and their Relation to Health. London: World Health Organization.

KARASEK, R.; BAKER, D.; MARXER, F.; AHLBOM, A. \& THEORELL, T., 1981. Job decision latitude, job demands, and cardiovascular disease: A prospective study of Swedish men. American Journal of Public Health, 71:694-705.

KELLY, J. E., 1978. A reappraisal of sociotechnical systems theory. Human Relations, 31:1069-1099.

KRISTENSEN, T. S., 1995. Demand-control-support model: Methodological challenges for future research. Stress Medicine, 11:17-26.
LANZARA, G. F., 1985. La progettazione: Da analisi funzionale ad attività dialogica-discursiva. In: Progettazione delle Nuove Tecnologie e Qualità del Lavoro (C. Ciborra \& G. F. Lanzara, cur.), pp. 3578, Milano: Franco Angeli.

MYIAMOTO, M., 1992. Gorin No Sho: A Estratégia de Vencer Sempre. São Paulo: Cultura Editores Associados.

ODDONE, I.; MARRI, G.; GLORIA, S.; BRIANTE, G.; CHIATTELLA, M. \& RE, A., 1986. Ambiente de Trabalho - A Luta dos Trabalhadores pela Saúde. São Paulo: Editora Hucitec.

PRILLELTENSKY, I., 1994. Morals and Politics of Psychology: Psychological Discourse and the Status Quo. Albany: State University of New York Press.

RODRIGUES, I. J., 1991. As comissões de empresa e o movimento sindical. In: O Sindicalismo Brasileiro dos Anos 80 (A. Boito Jr., org.), pp. 137-170, Rio de Janeiro: Paz e Terra

RODRIGUES, I. J., 1994. A questão da organização por local de trabalho: Dilemas e perspectivas no sindicalismo - CUT. In: Terceirização: Diversidade e Negociação no Mundo do Trabalho (H. S. Martins \& J. R. Ramalho, org.), pp. 216-232, São Paulo: Editora Hucitec/Núcleo de Estudos sobre Trabalho e Sociedade, Centro Ecumênico de Documentação e Informação.

RODRIGUES, L. M., 1974. Trabalhadores, Sindicatos e Industrialização. São Paulo: Brasiliense.

SATO, L., 1993. A representação social do trabalho penoso. In: O Conhecimento no Cotidiano-As Representações Sociais na Perspectiva da Psicologia Social (M. J. P. Spink, org.), pp. 188-211, São Paulo: Brasiliense.

SATO, L., 1997. Astúcia e Ambigüidade: As Condições Simbólicas para o Replanejamento Negociado do Trabalho no Chão de Fábrica. Tese de Doutorado, São Paulo: Instituto de Psicologia, Universidade de São Paulo.

SELIGMANN-SILVA, E., 1986. Crise econômica, trabalho e saúde mental. In: Crise, Trabalho e Saúde Mental no Brasil (V. A. Angerami, org.), pp. 54132, São Paulo: Traço.

SELIGMANN-SILVA, E., 1994. Desgaste Mental no Trabalho Dominado. Rio de Janeiro: Editora UFRJ/ Cortez Editora.

SELIGMANN-SILVA, E.; DELÍA, A. A. \& SATO, L., 1985. Trabalho e Saúde Mental dos Bancários. Relatório de Pesquisa. São Paulo: Departamento Intersindical de Estudos e Pesquisas de Saúde e dos Ambientes de Trabalho. (mimeo.)

SELIGMANN-SILVA, E.; DELÍA, A. A. \& SATO, L., 1986. A Saúde na Área Operativa do Metrô de São Paulo. Relatório de Pesquisa. São Paulo: Departamento Intersindical de Estudos e Pesquisas de Saúde e dos Ambientes de Trabalho/Sindicato dos Metroviários de São Paulo. (mimeo.)

SILVA FILHO, J. F. \& JARDIM, S. (org.), 1997. A $D a-$ nação do Trabalho - Organização do Trabalho e Sofrimento Psíquico. Belo Horizonte: Te Corá Editora.

SIMÃO, A., 1981. Sindicato e Estado (Suas Relações na Formação do Proletariado de São Paulo). São Paulo: Ática. 
SPINK, P., 1991a. O resgate da parte. Revista de Administração, 26:22-31.

SPINK, P., 1991b. Saúde mental e trabalho: O bloqueio de uma prática acessível. In: Psicologia e Saúde - Repensando Práticas (F. C. B. Campos, org.), pp. 91-102, São Paulo: Editora Hucitec.

VEZINA, M., 1998. Work-related Psychological Disorders: Alternative Approaches. Québec: Départemente de Médecine Sociale et Préventive, Faculté de Médecine, Université Laval. (mimeo.)

\section{Debate sobre o artigo de Leny Sato \\ Debate on the paper by Leny Sato}

\section{Saúde do trabalhador como liberdade}

Com freqüência as descrições de intervenções na área de saúde do trabalhador e as análises das relações trabalho-saúde, restringem o encaminhamento de soluções dos agravos à saúde relacionados ao trabalho, à negociação coletiva, envolvendo trabalhadores, empresários e eventualmente representantes governamentais. Por suposto, na instância da negociação coletiva os riscos ocupacionais são equacionados no seu conjunto traduzindo-se num maior impacto sobre a saúde. A discussão das negociações cotidianas no trabalho, tema pautado por Leny Sato, é oportuna por propor um outro foco de atenção para os profissionais envolvidos nesta área. É, também, uma reflexão em tempo frente às mudanças que estão ocorrendo nas relações de trabalho contemporâneas.

As negociações cotidianas colocam-se na dimensão das liberdades individuais, que proporcionam a contínua definição e redefinição de múltiplos coletivos, particulares, nos espaços de trabalho. A concepção de replanejamento do trabalho, como apresentada pela autora, significa os empregados exercerem maior controle e autonomia sobre sua vida no exercício de seu ofício, com o objetivo de preservar seu bem-estar e sua saúde. Como conseqüência, essa atitude também estimularia a produtividade pelo aperfeiçoamento dos processos de trabalho e redução de custos.

Leny Sato fundamenta teoricamente os elementos que regem as negociações cotidianas, e fixa sua análise no contraste de interesses conflitantes entre trabalhadores e gerência empresarial, e apresenta um exemplo de aplicação de relações cotidianas pelos trabalhadores de uma indústria de alimentos. É uma descrição bastante ilustrativa do potencial criativo gerado pelo exercício da liberdade, levando à racionalização do trabalho e maior segurança para os trabalhadores. Embora algumas teorias recentes das relações de trabalho incorporem na sua formulação a criatividade latente das negociações cotidianas, entre os empresários não é unânime a aceitação de que esta forma de liberdade deva ser estimulada a se manifestar e de que seja benéfica para a produção. É, habitualmente, refutada por um raciocínio con- 
trário, o papel desagregador que poderia vir a exercer.

A liberdade individual é indispensável para que os indivíduos tenham livre expressão e possam agir de forma mais criativa. Amartya Sen (2000), refere-se a um conceito de liberdade muito elementar e com expressivo significado para a saúde do trabalhador: a capacidade de sobreviver em vez de sucumbir à morte prematura. Salienta aquele autor que esta é obviamente uma forma de liberdade substancial, embora assinale que o leque de liberdades relevantes para o indivíduo pode ser muito amplo, a exemplo da liberdade de escolha do emprego. A questão de fato é a dificuldade de tratar a liberdade individual como um modelo "operacional" para equacionar os problemas de saúde nos ambientes de trabalho, cuja lógica de organização encontra-se definida pelos determinantes da produção capitalista. Mas se a negociação coletiva permite estabelecer planos gerais de proteção à saúde, é o exercício cotidiano da liberdade que permitirá ao trabalhador construir o seu modo de vida no trabalho.

Nas palavras de Leny Sato, as negociações cotidianas são virtualmente invisíveis para o observador apressado. É uma classificação que comporta grande parte dos profissionais ligados à saúde do trabalhador (mas, certamente, não o corpo gerencial das empresas), dadas à intensa demanda aportada nos serviços, atuações com ênfase em abordagens de cunho coletivo e, sobretudo, a característica de visitantes esporádicos aos locais de trabalho. Essas intervenções mais abrangentes, fundamentais, estarão sempre submetidas às particularidades do trabalho como exercido na rotina diária, no contexto da política empresarial e de interação social dos trabalhadores entre si e destes com a gerência. Essas pequenas intervenções que se materializam na microfísica do trabalho, criativas na estratégia de sobrevivência, estão fora do controle dos técnicos.

A liberdade participativa no mundo do trabalho requer um grau básico de instrução e o conhecimento sobre organização e processos de produção. Portanto, uma trajetória contínua é distinguível na obtenção da saúde e bem-estar no trabalho, e no seu curso, conflitos serão gerados, devendo-se considerar aqui a especificidade do fenômeno que a autora denomina “deslocamento de posições”. Muitas vezes os trabalhadores impõem mudanças à dinâmica planejada pela gerência, embora isso possa ser interpretado pelos empresários como uma ameaça à ordem empresarial. Por outro lado, os trabalhadores podem opor resistência aos “especialistas em saúde ocupacional”, simples- mente porque avaliam que seguir suas orientações, em princípio favoráveis à sua saúde, em determinadas conjunturas de política nacional ou da própria empresa pode significar a perda do emprego fato que, com lucidez, julgam mais grave do que o risco de doenças ou acidentes enquanto evento competitivo para a sua sobrevivência e de sua família. Deduz-se, portanto, que a conquista da saúde nos locais de trabalho não se dará por meio de tecnicalidades impostas interna ou externamente. Agir dentro das regras democráticas, ouvindo, orientando, esclarecendo e negociando com os trabalhadores é parte crucial do processo.

A tendência às economias e sociedades abertas como efeito da globalização traz, ao lado de novas oportunidades de negócios e benefícios para os consumidores, numerosos problemas para o trabalho, cuja regulamentação torna-se crescentemente precária. Os empregos informais, em geral, são menos seguros e incorporam menos vantagens sociais, aumentando a sensação de insegurança dos trabalhadores (Somavia, 1999). Nesse contexto, a preservação da saúde dos trabalhadores torna-se um objeto mais distante de abordagem pelos "especialistas em saúde ocupacional”. A prevenção de agravos à saúde do trabalhador por meio do replanejamento do trabalho, via negociações cotidianas, reconduz ao trabalhador a gerência de sua saúde. A questão da discussão sobre saúde do trabalhador e participação social é central para a elaboração de políticas em estruturas democráticas. Em uma perspectiva orientada para a liberdade, as liberdades participativas devem, necessariamente, ser parte das análises de políticas em saúde do trabalhador. É esta a essência da argumentação de Leny Sato. Pelo menos, é esta a minha leitura de suas idéias.

SEN, A., 2000. Desenvolvimento como Liberdade. São Paulo: Companhia da Letras.

SOMAVIA, J., 1999. Decent Work for All in a Global Economy: An ILO Perspective. 28 February 2002 $<$ http://www.ilo.org>. 
Raquel Rigotto

Departamento

de Saúde Comunitária, Faculdade de Medicina Universidade Federal do Ceará, Fortaleza, Brasil

\section{Um outro trabalho é possível !}

Muitas vezes as análises dos macroprocessos da Globalização e da Reestruturação Produtiva, em seus impactos sobre o mundo do trabalho, nos conduzem - com razão - ao reconhecimento da enorme concentração de capital e de poder em curso no sistema mundial de acumulação, da fragmentação da classe trabalhadora e do enfraquecimento do movimento sindical, da dificuldade em alimentar os laços de solidariedade, e apontam como perspectiva a emergência e o vigor de movimentos da sociedade civil também mundializados.

Sem perder de vista esse contexto, Leny Sato mergulha no cotidiano dos processos de trabalho e nos brinda com o registro de fendas, brechas, fissuras e nuances, identificadas a partir de um olhar atento e sensível no plano da empiria. (Como é bom quando alguém vem nos mostrar que não "está tudo dominado", que as pessoas continuam querendo dar sentido ao seu trabalho cotidiano e à sua existência!). Um olhar coerentemente articulado às construções teóricas em seu campo de saber, e também enriquecido por uma visão de mundo que incorpora as ciências sociais e políticas, a antropologia, entre outras disciplinas, numa trajetória complexa movida pelo desejo de contribuir num problema também complexo: a saúde dos trabalhadores.

Conduzida por seu olhar sobre as negociações cotidianas, pude revisitar depoimentos colhidos de trabalhadores nas indústrias recém-migradas para o Ceará, e verificar que elas também ocorrem aqui: "Quando eu abria os tambores de químico eu sentia aquele cheiro forte, inalava tudo. Aquilo é prejudicial à saúde, medo eu tinha... A gente procurava evitar, sabia que podia dar câncer... Nós combinávamos revezar entre a gente mesmo, cada dia quatro fazia uma coisa, senão viciava. Se eu ficasse só no solvente, acostumava com aquilo e não queria mais sair dali. Quando eu trabalhava lá, sentia que a minha vida estava diminuindo, por causa dos químicos..." (Trabalhador da indústria têxtil em Horizonte, Ceará) (I. Rosa \& R. Rigotto, comunicação pessoal).

A aproximação da dimensão simbólica da negociação é particularmente instigante. Se a organização do trabalho é, de fato, uma ideologia - "sentido a serviço do poder", como propõe Thompson (1995) - ela precisa ser compreendida na intimidade do contexto social específico em que é construída e aplicada. Além disso, as formas simbólicas produzidas e im- postas não são simples e passivamente absorvidas, mas passam por um processo contínuo de compreensão e interpretação, de discussão, apreciação - quando podem ser desafiadas, criticadas, contestadas e destruídas.

Tento compreender o imaginário que Josildo trazia consigo e a dinâmica por que passou ao longo do processo de negociação descrito por Leny Sato. A regra de ter de apagar as gravações - deletar o próprio trabalho?, trabalhar mais?, trabalhar de novo? Cansaço, raiva, indignação? O que fazer com esses sentimentos? Engolir, negar, afogar num porre, descarregar fora do trabalho? Negar-se à tarefa, resistir, brigar? E os tantos medos? Josildo parece ter assumido o desejo de que o trabalho - ou pelo menos esta regra - fosse diferente, a despeito da apregoada racionalidade técnica. Haveria um jeito de fazer diferente! E que seria possível implantar mudanças - ainda que num contexto assimétrico de forças. Se é que algo semelhante aconteceu no imaginário de Josildo e de seus companheiros, compreender a dinâmica destes dois momentos - assumir o desejo de mudança e acreditar na possibilidade dela - parece-me muito importante, por serem movimentos-chave para a ruptura com as representações instituídas e para a instituição de novas. Conhecer os processos facilitadores destas transformações do imaginário pode, por exemplo, iluminar conteúdos e metodologias adequados para as práticas educativas desenvolvidas por entidades sindicais, voltadas para a organização dos trabalhadores.

Em seguida (será que há uma seqüência tão lógica?!) vem a astúcia do grupo, como bem registra Sato: uma verdadeira e complexa análise estratégica de atores e da ação, onde os trabalhadores partilham, no plano coletivo, a insatisfação, o desejo e a crença na mudança; antecipam dificuldades e identificam possibilidades de alianças - quando se "deslocam" para o lugar dos outros atores e percebem a "com-fusão” de interesses em pontos específicos; dão visibilidade ao problema, negando-se à tarefa ou convocando as "mulheres da linha de cima" para ajudar nela; e vão ao supervisor de produção munidos de argumentos e propostas.

Saíram vitoriosos! E a vitória também tem uma dimensão simbólica, apontada por Leny Sato, que constitui-se certamente em um outro tipo de ganho para os trabalhadores. Acredito que, no processo de constituição desses sujeitos - e dos que acompanharam a história a partir de outras "linhas" -, ter conseguido mudar o que é dado como imutável, racional, poderoso, será uma experiência indelével - ao contrário dos seus carimbos nos frascos! 
Quiçá os profissionais da área de saúde do trabalhador possamos revisitar agora nossas representações sobre os trabalhadores e, a partir do reconhecimento de seu saber e capacidade de ação em defesa da saúde, resituar nosso papel e nossas práticas...

THOMPSON, J. B., 1995. Ideologia e Cultura Moderna: Teoria Social Crítica na Era dos Meios de Comunicação de Massa. Petrópolis: Editora Vozes.

Elizabeth Costa Dias

Departamento de Medicina Preventiva e Social, Faculdade de Medicina, Universidade Federal de Minas Gerais, Belo Horizonte, Brasi
Terminei a leitura do artigo da Dra. Leny Sato com um sentimento bom de esperança - tão em baixa nesses tempos de reestruturação produtiva, globalização de mercado, e precarização do trabalho -, quanto às possibilidades de mudança das condições de trabalho, na direção da saúde dos trabalhadores. Saúde como a "condição em que um indivíduo ou grupo de indivíduos é capaz de realizar suas aspirações, satisfazer suas necessidades e mudar ou enfrentar o ambiente" (Rey, 1999:687). Saúde como um recurso para a vida diária e não um objetivo de vida. Um conceito positivo que considera e enfatiza os recursos sociais e pessoais, tanto quanto as condições físicas.

A percepção da saúde como recurso para a vida diária - o cotidiano - ganha concretude na experiência desses trabalhadores de uma indústria de alimentos. Ao organizarem seu trabalho segundo uma racionalidade distinta daquela proposta pelo corpo gerencial da empresa, através de um processo negociado, fazem a "recomposição dos processos de trabalho sobre os escombros dos sistemas de produção industriais do início do século XX” (Guattari, 1990:48). Nas palavras de Guattari, produzindo "uma subjetividade criacionista, tanto no plano individual quanto no plano coletivo".

No texto, a autora detalha o processo desse replanejamento do trabalho de forma clara e bem sistematizada, permitindo que, mesmo aqueles pouco familiarizados com a teoria, possam entender o fenômeno, observado em múltiplas formas, no cotidiano do trabalho.

A rigor, a busca de "outras racionalidades" para organizar o trabalho, sempre esteve presente no denominado "chão de fábrica", como demonstrado por Danilellou et al. (1989), a partir das diferenças observadas entre o trabalho prescrito e o trabalho real. Os trabalhadores, individualmente ou em grupo, a partir de um "saber fazer" aprendido no trabalho, desenvolvem estratégias com a finalidade de faci- litar a tarefa, poupar esforço ou energia, manifestar sua autonomia e ou resistência aos mecanismos de controle, ou ainda, como formas de suporte social no trabalho, na concepção de Johnson (1989), reconhecidamente importantes para a preservação da saúde.

Há cerca de dois anos, tivemos a oportunidade de acompanhar o estudo de um grupo de trabalhadores da limpeza urbana de Belo Horizonte, que resultou na monografia de conclusão da Residência em Medicina Social/Medicina do Trabalho, da Dra. Ciwannyr Assumpção (2000). A questão que o norteou foi a de entender como um grupo de trabalhadoras de meia idade e portadoras de queixas osteo-musculares, permaneciam, por opção, trabalhando em atividades de varrição e limpeza de vias públicas. A análise do trabalho e as entrevistas com os trabalhadores mostraram que isso somente foi possível, devido a um rearranjo do trabalho, desenvolvido pelas equipes responsáveis pelas tarefas, com uma certa cumplicidade dos supervisores das turmas. Abandonando a rigidez das prescrições da organização e os papéis tradicionais, os trabalhadores organizaram as atividades de modo tal, que aquelas que demandavam maior esforço físico e agilidade, eram desempenhadas pelos indivíduos mais jovens e com mais força física de cada equipe, permitindo que a tarefa do dia fosse completada com sucesso e em menor tempo, com uma redução real da jornada de trabalho e a manutenção no trabalho de trabalhadoras com limitações, impostas pela idade e pelos problemas osteo-musculares, mas que queriam continuar trabalhando, e não poderiam fazê-lo no sistema tradicional. De modo distinto do estudo conduzido pela Dra. Leny Sato, eram trabalhadores com pouca ou nenhuma escolaridade, de uma empresa pública do setor de serviços, com predomínio de mulheres, mas que se organizaram para trabalhar menos tempo e apoiarem-se.

Observação semelhante foi feita por Assunção (1998), estudando trabalhadores de um restaurante universitário. O reconhecimento da importância da experiência e da competência profissional de um grupo de trabalhadoras mais idosas para o sucesso ou o alcance dos objetivos do processo produtivo, foi o ponto de partida para a decisão da equipe de trabalho de desenvolver estratégias, de modo a aproveitar o "savoir faire" dessas trabalhadoras e permitir sua permanência no trabalho, a despeito das limitações impostas pela idade e pela doença.

Reforçando a importância dessa questão, é importante registrar que, ganha força entre os profissionais que se dedicam ao campo da Saúde do Trabalhador, a idéia de que nem sempre 
a melhor alternativa para o trabalhador que adoece no trabalho é o seu afastamento da atividade. Quase sempre, o ideal é mudar a condição de trabalho permitindo que ele ou ela continue trabalhando.

Poder-se-ia perguntar quem, ao final, ganha com esses rearranjos? A resposta parece simples: ganham todos. Sem dúvida o sistema e os organizadores da produção ganham. Particularmente, se considerarmos as exigências crescentes de produtividade, diversidade e qualidade dos produtos, nos mercados globalizados. Mas os trabalhadores, também ganham. A curto prazo, conquistam algum tempo livre ou a possibilidade de dispender menos esforço no trabalho. Em uma perspectiva mais ampliada, ganham força, reforçam a auto-estima, aumentam a resiliência, palavra emprestada da ecologia para indicar a capacidade de resistir aos traumas e pressões e o poder de gerenciar suas vidas. É uma expressão do empoderamento (a palavra é feia, mas a idéia é bonita) proposto pela estratégia da promoção da saúde no trabalho. Devemos saudá-los como sinal da possibilidade de tempos melhores e de ter esperança.

ASSUMPÇÃO, C. M., 2000. Estudo das Atividades de Varrição, Carrinheiro e Coleta na SLU, como Contribuição para as Práticas do Serviço de Medicina do Trabalho. Monografia, Belo Horizonte: Faculdade de Medicina, Universidade Federal de Minas Gerais.

ASSUNÇÃO, A. A., 1998. De la Déficience à la Gestion Collective du Travail: Les Troubles Musculo-Squelettiques dans la Restauration Collective. Thèse de Doctorat, Paris: École des Hautes Études, Ministére de l'Education Nationale, de la Recherche et de la Technologie.

DANIELLOU, F.; LAVILLE, A. \& TEIGER, C., 1989. Ficção e realidade do trabalho operário. Revista Brasileira de Saúde Ocupacional, 17:7-13.

GUATTARI, F., 1990. As Três Ecologias. Campinas: Papirus.

JOHNSON, J. V., 1989. Collective control: Strategies for survival in the workplace. International Journal of Health Services, 19:540-545.

REY, L., 1999. Dicionário de Termos Técnicos de Medicina e Saúde. Rio de Janeiro: Guanabara Koogan.
Carlos Machado de Freitas

Centro de Estudos em Saúde do Trabalhador e Ecologia Humana, Escola Nacional de Saúde Pública, Fundação Oswaldo Cruz, Rio de Janeiro, Brasil
Dos limites e das possibilidades das micronegociações para o replanejamento do trabalho

Para debater o artigo de Leny Sato, tomo como referência inicial as palavras do samurai Myiamoto, para quem o fogo, grande ou pequeno, possui sempre a extraordinária força de transformação. Atualizando para nossos dias seu enunciado cunhado no século XVII, e tendo como metáfora um dos grandes problemas atuais, os perigos associados à queima de resíduos químicos, podemos considerar que embora o fogo possua sempre a capacidade de transformação, seus subprodutos podem, dependendo da combinação que envolve as características dos produtos em questão e o grau da temperatura do fogo empregado, ser tão ou mais perigosos do que aqueles que se pretendia eliminar, com conseqüências que se estenderão no espaço e no tempo.

Nos dias atuais, de quebra da Consolidação das Leis do Trabalho e em que a palavra chave é negociação, cabe trazer mais elementos para a reflexão de situações como as descritas no artigo em questão. Nestes dias, no âmbito mais global, verifica-se uma contração da classe trabalhadora e industrial, com sua conseqüente fragmentação, havendo o declínio de sindicatos de categorias inteiras, assim como das negociações centralizadas. O resultado disso é uma ampliação das negociações localizadas nas fábricas, com uma força de trabalho dividida entre trabalhadores do núcleo e periferia, sem o compromisso da luta corporativa e o conseqüente esfacelamento dos benefícios sociais padronizados (Kumar, 1997).

Neste cenário global ocorrem múltiplas e complexas interações, visíveis e invisíveis, que se manifestam no dia-a-dia dos locais de trabalho, nos obrigando sempre a olhar e perguntar sobre as possibilidades e os limites das negociações que aí possam ocorrer. Negociações que envolvem uma multiplicidade de formas, entre estas, aquelas que nas palavras de Sato, são “...micronegociações (...) [conduzidas por pessoas comuns] configurando-se como processos de replanejamento negociados (...), [que] ocorrem independente da ação política coletiva que pressupunha uma estratégia articulada...".

Essas micronegociações, podem simplesmente manifestar a continuidade de tantas outras que sempre ocorreram nos locais de trabalho, desde os primórdios da industrialização, mas que nenhuma ou pouca atenção receberam dos pesquisadores da área. Podem tam- 
bém manifestar uma tendência crescente para "novas formas de negociação", que resultam menos de ganhos dos trabalhadores, mas de perdas, dado o cenário de fragmentação e declínio de sindicatos e de outras estratégias articuladas. Nesse caso, e adotando essa perspectiva, essas micronegociações podem estar simplesmente manifestando a tendência atual de transformar as necessidades coletivas em atos individuais ou mesmo de pequenos grupos. Fragmentam-se ainda mais as ações coletivas e articuladas, como as tradicionalmente conduzidas por sindicatos representantes de toda uma categoria e, considerando a perspectiva de Bauman (1999), para quem o mercado abomina a autogestão e a autonomia, só se aceitam as reivindicações que beneficiem a lógica do mercado. Nas palavras de Bauman (1999:291), se “...os padrões de mercado não são atingidos, o melhor que se pode esperar é a indiferença do mercado. Na pior das hipóteses, deve-se contar com a hostilidade do mercado...”. Nesses cenários, a ampliação das micronegociações representaria muito mais perdas para os trabalhadores do que ganhos, já que replanejamentos seriam aceitos, desde que, na lógica do mercado, possam representar aspectos como maior lucro, melhoria do produto, redução do tempo de produção, sem que isso represente maior custo em termos de redução da jornada, proteções coletivas e individuais, maior autonomia dos trabalhadores para decidir sobre suas atividades, proteção social, etc.

Por outro lado, essas micronegociações podem representar o aparecimento ou mesmo ampliação de formas de ação política diferentes daquelas que tradicionalmente concebemos. Trata-se da subpolítica que, de acordo com Beck (1997:35), distingui-se da política “...porque (...) permite que os agentes externos ao sistema político ou corporativo apareçam no cenário do planejamento social (este grupo inclui os grupos profissionais e ocupacionais, a intelligentsia técnica das fábricas, as instituições e o gerenciamento de pesquisa, trabalhadores especializados, iniciativas dos cidadãos, a esfera pública e assim por diante), e, em segundo porque não somente os agentes sociais e coletivos, mas também os indivíduos, competem com este último e um com o outro pelo poder de conformação emergente do político". Para Beck (1997), a subpolítica não pode ser vista como representando somente a perda de poder de negociação ou minimização da política. Mais do que isso, significa moldar a sociedade de baixo para cima, oferecendo oportunidades crescentes de que grupos até então não envolvidos na tecnificação essencial no processo indus-

trial, entre estes, os trabalhadores no local de trabalho, tenham uma voz e uma participação no arranjo da sociedade. Nessa perspectiva, a micronegociação pode representar a constituição de formas alternativas de ação política dos trabalhadores, tendo implicações não só nos seus locais de trabalho, mas na sociedade como um todo, ainda que de forma diferente da que concebemos até então. Se é isso, cabem algumas perguntas que o próprio Beck (1997), formula e que devem fazer parte dos debates sobre micronegociações e replanejamento do trabalho, entendidos como inseridos na subpolítica. Entre essas: Quais são suas fontes de poder, suas possibilidades de resistência e seu potencial para a ação estratégica? Estão emergindo novas formas e fóruns organizacionais de debate negociação? Implicam em conflitos com relação às formas tradicionais de se fazer política, como os sindicatos, por exemplo? Qual o nível e a qualidade de organização possuem os grupos envolvidos nessas micronegociações?

BAUMAN, Z., 1998. Globalização: As Conseqüências Humanas. Rio de Janeiro: Jorge Zahar Editor.

BECK, U., 1997. A reinvenção da política: Rumo a uma Teoria da Modernização Reflexiva. In: Modernização Reflexiva - Política, Tradição e Estética na Ordem Social Moderna (U. Beck, A. Giddens \& S. Lash, org.), pp. 11-71, São Paulo: Editora Unesp.

KUMAR, K., 1997. Da Sociedade Pós-Industrial à Sociedade Pós-Moderna-Novas Teorias Sobre o Mundo Contemporâneo. Rio de Janeiro: Jorge Zahar Editor.

René Mendes

Departamento de Medicina Preventiva e Social, Faculdade de Medicina, Universidade Federal de Minas Gerais Belo Horizonte, Brasi
Tendo sido incluído entre aqueles que tiveram o privilégio especial de conhecer o excelente trabalho de Leny Sato, antes de sua publicação, em função da interessante metodologia introduzida pelos editores de Cadernos de Saúde Pública, imagino que o exercício de analisar este trabalho e de identificar ângulos para o debate possa ser tão rico e diverso, de modo tal que, dificilmente, os colegas que receberam idêntica tarefa à minha, irão se repetir. Isto porque o trabalho da Professora Sato, abre, de fato, um leque interminável de "ganchos" para um profícuo debate no meio acadêmico e profissional vinculado às questões de Saúde Pública e Saúde do Trabalhador, em torno de questões extremamente avançadas e atuais.

Dos muitos e diversos ângulos de análise possíveis, gostaríamos de enfocar aqui, apenas o que se refere diretamente a nós, profissionais 
comprometidos com a Saúde do Trabalhador, tomando, para tanto, a última parte deste interessante trabalho.

Assim, entre muitas coisas lindas e extremamente oportunas de serem ditas, a autora nos convida a refletir sobre o nosso papel, entendendo que "a prática dos profissionais que nela [área de saúde do trabalhador] atuam será a de interlocutores que venham a facilitar $o$ processamento do planejamento/replanejamento do trabalho concebida como atividade dialógico-discursiva (...), potencializando e ampliando as mudanças de organização do processo de trabalho, conduzidas sempre, a partir do grupo primário de trabalho" (grifo introduzido).

Esse conceito expressado pela autora, pinçado dentre outros muito bem enunciados, nos obriga - "profissionais" e "técnicos" atuantes no campo da Saúde Pública - a refletir sobre o as dimensões deste papel de "interlocutores", bem como os requisitos para o exercer, com competência. O modo como os dicionários definem o termo interlocutor - "aquele que fala com outro; aquele que fala em nome de outro" já nos chama a atenção à complexidade dessa tarefa, para não dizer a enorme responsabilidade que pesa sobre os ombros do que fala, principalmente se fala em nome de outro... Responsabilidade pesada, vista por um lado; privilégio e desafios ímpares, visto por outro.

É requisito primitivo do desenvolvimento do ser humano, que para falar é preciso ouvir assim as crianças aprenderam a falar, e por isso os "surdos" congênitos se tornam "mudos" e para falar em nome de outro é preciso ouvir, muito mais!

Eis aqui uma das mais impressionantes dificuldades dos "profissionais" de saúde: saber ouvir, antes de falar... Particularmente essencial no campo da saúde dos trabalhadores, onde não necessariamente os que falam são "pacientes", e sim cidadãos ativos e, como bem demonstrou a autora, capazes de planejar ou replanejar o trabalho, mesmo sendo apenas "meninos", "mulheres" ou apenas "os de baixo"...

Nesse sentido, a autora corretamente destaca, em outra parte de seu trabalho, o preconceito e o viés do "olhar arrogante, que apenas vê como mudança aquelas que assim consideremos..."

Outrossim, espera-se, de acordo com a expectativa da autora, que esses interlocutores "venham a facilitar o processo do planejamento/replanejamento do trabalho (...) potencializando e ampliando as mudanças de organização do processo de trabalho, conduzidas sempre, a partir do grupo primário de trabalho" (grifos introduzidos).
Sem reduzir a riqueza do trabalho da Professora Leny Sato ao ângulo que escolhemos analisar, as inúmeras reflexões desencadeadas por seu trabalho incluem a detecção de um verdadeiro chamamento e quase uma provocação a todos nós que militamos na Saúde Pública/ Saúde do Trabalhador, no sentido de nos (re) avaliarmos frente a esses requisitos colocados pela autora.

Referimo-nos, sem ordem hierárquica, a competências como saber ouvir, saber falar, saber falar com o outro, saber falar pelo outro, saber facilitar (o processo de planejamento/replanejamento do trabalho), ser capaz de potencializar, de ampliar as mudanças... Enfim, a capacidade de encontrar o nosso espaço de competência, que deveria estar eqüidistante (e que distante...), de um lado, do "olhar ingênuo" que considera (à luz das experiências e vivências observadas no cotidiano) resolvido o problema do planejamento/replanejamento da organização do processo de trabalho e da prevenção em saúde do trabalhador - e, no outro extremo, do "olhar arrogante", que apenas vê como mudança aquelas que assim consideremos.

Lendo este lindo trabalho e buscando dele extrair lições para a nossa vida, elegemos este ângulo de análise, para continuar refletindo. E, principalmente, para questionar condutas e posturas profissionais prevalentes, que, na verdade, mais se aproximam dos extremos, seja da ingenuidade, seja da arrogância. Respostas sérias a este desafio, irão requerer importantes investimentos na construção de novas competências, na reconstrução de outras e, certamente, na demolição ("desconstrução"?) de muitas. 


\section{A autora responde}

The author reply

Leny Sato

\section{A vida cotidiana no trabalho: a ambigüidade possibilitando múltiplas leituras}

A oportunidade de ter leitores debatendo idéias e pontos de vista a partir de uma leitura da realidade de saúde \& trabalho por mim apresentada neste artigo, antecipa algumas reflexões e posicionamentos dentre tantos outros possíveis que poderão se fazer presentes nas diversas leituras. Um texto sempre traz um sem-número de possibilidades de interpretação, como sabemos, e possibilita ancorar distintos racionais, quer para corroborar, quer para refutar suas proposições, e essa multiplicidade é potencializada pelo fato de estarmos aqui situados num campo em que diversas disciplinas e profissionais nele atuam: a Saúde do Trabalhador.

Da multiplicidade de temas levantados pelos debatedores e que poderiam ser por mim eleitos para dar continuidade ao debate, tomo em especial aquele que parece ter assumido especial relevância: os significados e os reflexos das negociações cotidianas para as relações de trabalho (regulamentação, desregulamentação) e para as condições de saúde e trabalho. Para Victor Wünsch Filho, Raquel Rigotto e Elizabeth Costa Dias, a leitura sobre a descrição dos fenômenos suscitou avaliações e sentimentos de esperança, possibilidade de alcançar a liberdade e a conclusão de que nem tudo está dominado. Para Carlos Machado de Freitas, as negociações cotidianas, ao contrário, estariam no âmbito da subpolítica e poderiam vir ao encontro da intensificação da precarização das relações de trabalho, expresso, entre nós, por exemplo, na flexibilização da CLT; preocupação nesse mesmo sentido é também expressa por Wünsch Filho, ao afirmar que o debate sobre as negociações cotidianas tornase atual frente às mudanças das "relações de trabalho contemporâneas".

O estudo das micronegociações situa-se no âmbito dos estudos sobre o cotidiano e, como tal, não focaliza aqueles processos desenvolvidos pelos sujeitos políticos instituídos, como as negociações coletivas. Ao contrário, dirige a atenção para o dia-a-dia, no qual o trabalho, os trabalhadores, as relações de poder, as resistências, as imposições hierárquicas e as negociações se dão. Focaliza o comezinho, o não memorável, a vida comum de todo o homem no local de trabalho. Nesse âmbito, focalizamse os processos nos quais, como afirma Wünsch Filho, "proporcionam a contínua definição e redefinição de múltiplos coletivos", ao modo do que Thompson (1998), descreve como as negociações desenvolvidas pelas "multidões", as quais "têm todos os formatos e tamanhos" (Thompson, 1998:82), e é volátil. Conforme Tedesco (1999:23), o campo da sociologia do cotidiano tem o mérito de "o mesmo demonstrar a possibilidade de estabelecer ligações entre os grandes dispositivos sociais e os que regulam a vida cotidiana, bem como em resgatar o reaparecimento do sujeito face às estruturas, aos sistemas e ao instituído no vivido". Assim, o campo de estudos do cotidiano abre a possibilidade de se reconhecer as ambigüidades, a dinâmica conformismo e resistência (Chaui, 1993), e a da deferência e rebeldia (Thompson, 1998); enfim, fenômenos que são isto e aquilo ao mesmo tempo (Chaui, 1993). Não é sem razão, então, que a tematização das micronegociações suscita tanto avaliações e reflexões de otimismo - em que a liberdade do homem comum parece ser possível - e aquelas que tomam a vida cotidiana como o espaço da impossibilidade de escapar à estrutura social.

É próprio do estudo do cotidiano pesquisar a relação entre o todo e a parte (Diehl, 1999), compreender as interações face-a-face, os processos grupais, e toda uma série de dinâmicas interativas que constroem a tecitura dos lugares, dando-lhe formas, conteúdos, corpo. Sendo assim, se focalizei no estudo um âmbito da realidade social e simbólica, isso não significa que tenha tido a intenção de apresentar um "remédio" ou um único caminho através do qual a negociação, visando o replanejamento do trabalho, deva dar-se. Procurei ilustrar, descrever e compreender um tipo de interação negociada que também redunda no replanejamento do trabalho. Assim, longe de ter a intenção de propor que as negociações cotidianas venham a substituir as negociações em outros níveis, no artigo, afirmo: "Entendemos, seguindo Gardell (1982b), que o replanejamento do trabalho visando a promoção da saúde, deverá ser conduzida em múltiplos níveis - o das centrais sindicais, dos sindicatos, das OLTs e CIPAs e dos trabalhadores comuns - aproveitando-se da força que cada um deles tem", posição essa apreendida na leitura de Wünsch Filho. Pretendo, enfim, ilustrar que o cotidiano é também o espaço no qual o mundo acontece e que nele, as negociações ocorrem de um modo peculiar, onde homens e mulheres desinvestidos do papel de representação, os quais, nos moldes da 
multidão descrita por Thompson (1998), impõem o limite da exploração através de uma espécie de "sensibilidade irritável", em que, no momento estudado por ele, o início do século XVIII, “a subordinação está se tornando objeto de negociação (embora entre partes gritantemente desiguais" (Thompson, 1998:42). Assim sendo, se concordo com Freitas, em seu texto de debate, que tais negociações são a continuidade de "tantas outras que sempre ocorreram nos locais de trabalho, desde os primórdios da industrialização", não considero que descrever e tomar o cotidiano e as negociações que aí ocorrem devam ser acompanhados do advérbio simplesmente. Como afirma Freitas, embora possam não ser novas, para nós assim serão, caso as ignoremos. E se isso ocorre, fenômenos que pretendemos estudar no campo da Saúde do Trabalhador são deixados de lado, como se fossem de somenos importância. No entanto, se por ignorá-los eles não existem para nós, isso não significa que não existam para outros, para os trabalhadores que cotidianamente se vêem na urgência de enfrentar, com a força e a fraqueza que têm, o dia-a-dia. Trata-se, como diz Certeau (1994), de encontrar formas de escapar ao poder, sem deixá-lo.

Ao descrever esses fenômenos (e descrever, entendo, é já um trabalho de interpretação), não me propus - e nem teria o poder para tanto - a incentivar ou prever que as micronegociações sejam uma "tendência atual de transformar as necessidades coletivas em atos individuais ou mesmo de pequenos grupos", como pontua Freitas. O mundo no chão de fábrica tem uma dinâmica própria, existe para além do nosso olhar! Ao contrário, como pesquisadora, a minha intenção é propor uma leitura possível sobre o cotidiano de trabalho e, nele, sobre a saúde dos trabalhadores. Isso não significa, entretanto, que acredite ser possível alcançar a "neutralidade" científica, mas pus-me, ao lado dos trabalhadores, por cerca de oito meses, acompanhando o dia-a-dia, vendo e procurando compreender a visão que eles tinham sobre o seu trabalho, sobre sua saúde, sobre os problemas que enfrentavam e como lidavam com as constrições, esforços e com o sofrimento. E nesse processo, nem sempre vemos aquilo que descansa nossos olhos e acalma nossos sentimentos. Nesse sentido, aponto que as micronegociações têm limites; que além delas, existem negociações frustradas e imposições de mudanças a partir da gerência. De modo algum, trata-se de considerar que o problema de saúde do trabalhador esteja resolvido com essas micronegociações.

Entendo que no campo da Saúde do Trabalhador, também o cotidiano é um dos focos pri- vilegiados de atenção: o que fazemos quando desenvolvemos os estudos empíricos sobre condições de trabalho e saúde? O que se faz quando se dirige para as atividades de vigilância nos locais de trabalho? Focaliza-se o cotidiano, as condições de trabalho diariamente enfrentadas pelos trabalhadores - a "microfísica do trabalho" como disse Wünsch Filho em seu texto de debate - afinal, são essas as condições cotidianas, que entendo, se pretende conhecer e mudar. Focalizar o cotidiano de trabalho, certamente, não implica em abstrai-lo da estrutura social (infra e superestrutura), mas tampouco, deduzir o seu funcionamento a partir desta estrutura. Isso tudo nos mostra que a vida cotidiana não é simples, a não ser que o nosso olhar a simplifique.

Retoma-se aqui, o debate, sempre em pauta sobre as grandes questões para as ciências sociais e humanas: a relação indivíduo-sociedade, individual-coletivo, mundo objetivo-mundo subjetivo, realidade material-realidade simbólica.

Outra dimensão importante, levantada por Rigotto, diz respeito aos significados possíveis de serem construídos e a experiência "indelével" acerca da possibilidade, ainda que limitada, de pensar de outro modo e de provocar o questionando da ideologia gerencial, ainda que não a desmonte, ainda que continue existindo - como também lembrou Dias em seu texto de debate - o hiato entre o trabalho prescrito e o trabalho real. Sabem os trabalhadores que, dada a assimetria de poder presente no espaço fabril, eles devem controlar a expressão do mundo subjetivo, sabem que estão num palco - nos moldes descritos por Goffman (1985) - e que a invenção deve ser tática, aproveitando as oportunidades que se apresentam a conjuntura (Certeau, 1994; Thompson, 1998).

Sobre a atuação dos profissionais da área de saúde do trabalhador, presentificada neste debate, por exemplo, em Rigotto e em Mendes, reafirmo que se atribuímos estatuto epistemológico ao conhecimento/subjetividade operária (Boltanski, 1989; Moscovici, 1961; Oddone et al., 1986) e com ele dialogamos, parece-me ser uma decorrência lógica considerar que as micronegociações têm estatuto político e que põem em prática o que esse conhecimento constrói. Se o primeiro difere do conhecimento construído pelas diversas ciências, as segundas também diferem das negociações em outros níveis. Reconhecer e compreender esses fenômenos sempre será um bom ponto de partida para a construção do diálogo com os trabalhadores e seus órgãos de representação, para a condução das práticas profissionais em saúde do trabalhador. 


\section{Referências}

BOLTANSKI, L., 1989. As Classes Sociais e o Corpo. Rio de Janeiro: Graal.

CERTEAU, M., 1994. A Invenção do Cotidiano-Artes de Fazer. Petrópolis: Vozes.

CHAUI, M., 1993. Conformismo e Resistência. Aspectos da Cultura Popular no Brasil. São Paulo: Brasiliense.

DIEHL, A. A., 1999. Apresentação. In: Paradigmas do Cotidiano: Introdução à Constituição de um Campo de Análise Social (J. C. Tedesco, org.), pp. 7-10, Santa Cruz do Sul: Edunisc.

GOFFMAN, E., 1985. A Representação do Eu na Vida Cotidiana. Petrópolis: Vozes.

MOSCOVICI, S., 1961. A Representação Social da Psicanálise. Rio de Janeiro: Zahar.

ODDONE, I.; MARRI, G.; GLÓRIA, S.; BRIANTE, G.; CHIATTELLA, M. \& RE, A., 1986. Ambiente de Trabalho - A Luta dos Trabalhadores pela Saúde. São Paulo: Editora Hucitec.

TEDESCO, J. C., 1999. Paradigmas do Cotidiano: Introdução à Constituição de um Campo de Análise Social. Santa Cruz do Sul: Edunisc.

THOMPSON, E. P., 1998. Costumes em Comum - Estudos sobre a Cultura Popular Tradicional. São Paulo: Companhia das Letras.

Recebido em 7 de março de 2001

Versão final reapresentada em 16 de julho de 2001

Aprovado em 6 de agosto de 2001 